\title{
Persistent vertical post-facectomy and associated thyroid disease
}

\author{
Diplopia vertical persistente pós-facectomia \\ e tireoidopatia associadas
}

Daniel Amorim Leite', Galton Carvalho Vasconcelos ${ }^{1}$, Ana Rosa Pimentel Figueiredo', Henderson Celestino de Almeida ${ }^{1}$

\begin{abstract}
$\underline{\text { ABSTRACT }}$
The authors report a case of a 69 year-old woman who developed persistent vertical deviation and diplopia after extracapsular cataract surgery and had a positive past history of thyroid disease. The authors emphasize the need of for detailed orbit propedeutics in order to rule out restrictive strabismus associated with post-facectomy diplopia.
\end{abstract}

Keywords: Diplopia; Cataract; Graves' disease; Ophthalmologic surgical procedures; Anesthesia; Case reports

\section{RESUMO}

Os autores relatam o caso de uma paciente feminina de 69 anos que desenvolveu diplopia vertical persistente após facectomia extracapsular sob anestesia peribulbar. Paciente apresentava história de tireoidopatia tratada o que tornou a condcução da diplopia mais complexa. Os autores enfatizam a necessidade de se realizar propedêutica orbitária detalhada para se descartar quadros restritivos da musculatura extraocular associados à diplopia pós-facectomia.

Descritores: Diplopia; Catarata; Doença de Graves; Procedimentos cirúrgicos oftalmológicos; Anestesia; Relatos de casos

\footnotetext{
${ }^{1}$ Universidade Federal de Minas Gerais, Belo Horizonte, MG, Brasil. 


\section{INTRODUCTION}

$\mathbf{P}$ ost-facectomy diplopia without complications is a disappointing event for the surgeon. ${ }^{(1)}$ When such a situation is monocular, it can be explained by uncorrected refractive errors, maculopathy, corneal irregularities or intraocular lens.On the other hand, when it is binocular, it can be related to anisokonia or loss of ocular alignment.This loss occurs due to decompensation of previous phorias, restrictive mechanisms, paralysis, myasthenia gravis and skew-deviation ${ }^{(2)}$. The vertical diplopia after peribulbar or retrobulbar anesthesia can cause paresis, contractures and hyperfunction ${ }^{(3)}$, and has incidence after cataract surgery estimated in $0.3 \%$, which can be explained by five mechanisms:anisokonia, prior diplopia masked by visual impairment, damage to the extraocular muscles by sutures in the perioperative period (making reins), allergic or toxic reaction to anesthetic agents, and direct trauma to muscles by anesthetic block $^{(1,4)}$.

In this study, the authors discuss the possible causes of vertical diplopia after cataract surgery in patients with previous positive history of thyroid disease.

\section{Case Report}

Female patient, 69-years old,was referred to the strabismus sector of Hospital São Geraldo-HC-UFMG complaining of "double vision" after cataract surgery.She presented binocular, vertical diplopia for far and near sight perceived two days after completion of extracapsular facectomy in the right eye (RE).During the same period, she reported bruising and intense eyelid edema.The patient also had facectomy in the left eye (LE) in the same year, with no complications.

The patient medical record states therapy with radioactive iodine for uncontrolled hyperthyroidism 17 years earlier.Currently, the patient makes use of levothyroxine.It was also reported breast cancer 25 years before, which was surgically treated.

The patient's ophthalmological examination showed visual acuity RE -1.50 -3.25 x 10 (1.0) and LE -3.00 -3.25 x 145 (0.6). Ishihara, Amsler grid, visual field of confrontation and computerized perimetry were normal.Pupils and palpebral fissures were unchanged.The Hertel exophthalmometer resulted RE $18.0 \mathrm{~mm}$ and LE $19.0 \mathrm{~mm}$, with base 110. Pseudophakia on both eyes with centered intraocular lenses.Fundoscopy had no changes.

The coverage test showed exotropia (XT) of 4 prismatic diopters (PD) for far sight and 8 DP for near sight associated with right hypotropia of 8 PD for far sight.Down sight showed right hyperopia of $45 \mathrm{PD}$ associated to esotropia of $4 \mathrm{PD}$.(figure 1) At this date, glasses with full prism for far sight were prescribed:3PD in the RE superior base,and $2 \mathrm{PD}$ in the LE inferior base.In the versions, limitation of elevation was noticed.The forced duction test showed no restrictions at all sight positions.

Nuclear magnetic resonance was performed in the orbits (coronal and axial sections), which suggested a slight thickening of the muscle (figure 2). Laboratory tests of the patient (TSH, T4 and anti-TPO) were normal.

Glasses were prescribed associated to prisms to far and near sight, with good control of diplopia in the primary position and reading position.

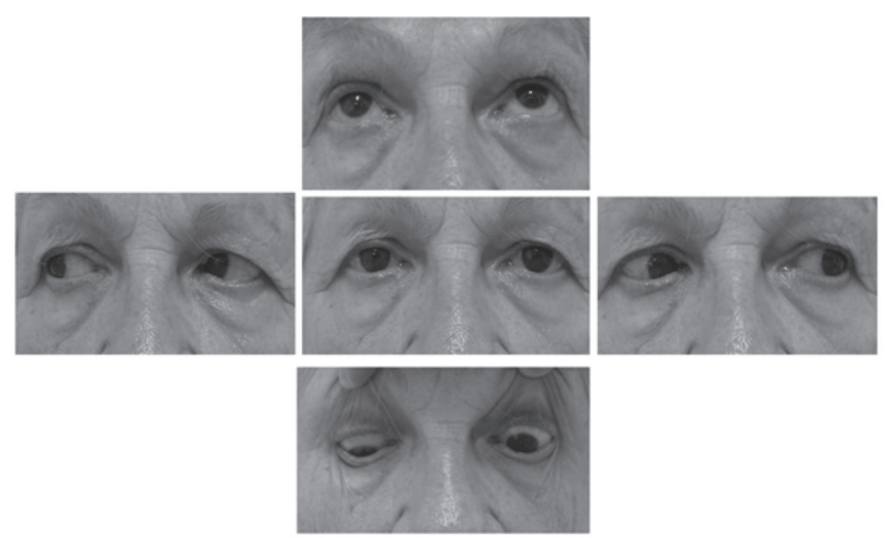

Figure 1: Versions of the patient:Right hipertropia in primary position, with worsening in depression and limitation of elevation, without restriction.
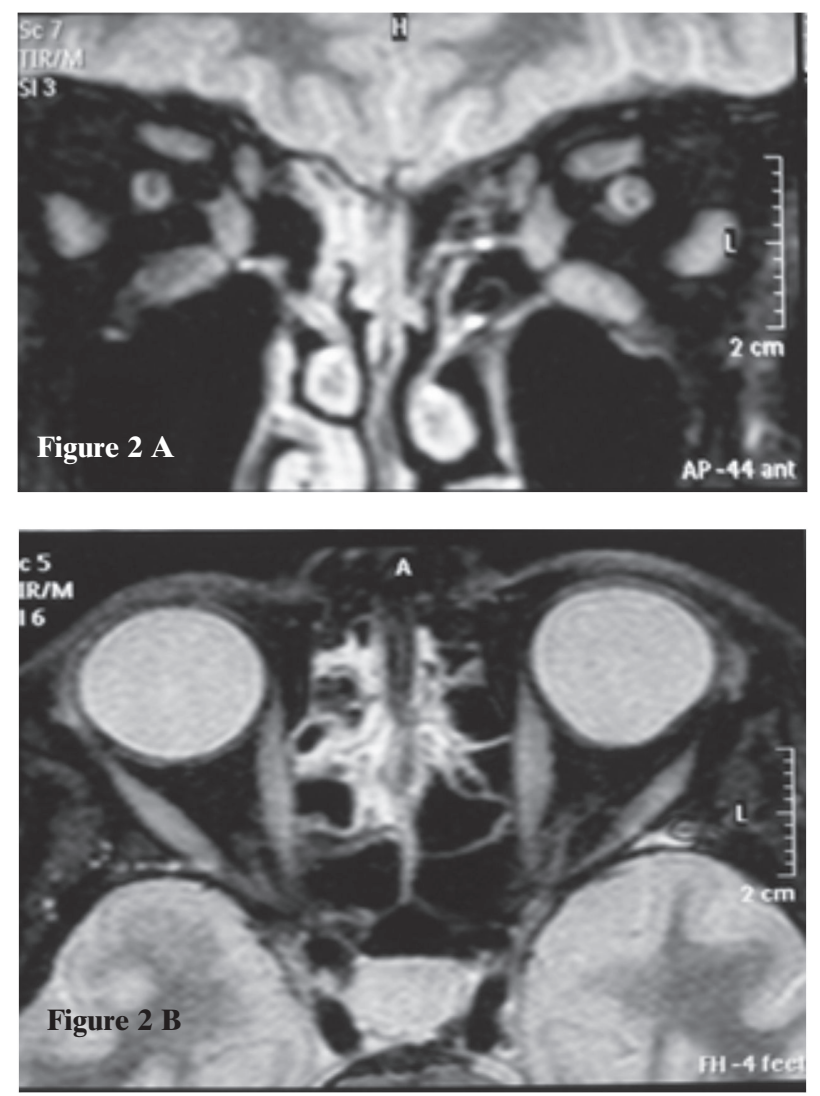

Figure 2: A - Magnetic resonance imaging (coronal section) showing thickening of the extrinsic ocular muscles.B - Axial section demonstrating normality of the horizontal rectus muscles

\section{Discussion}

Successful diplopia after facectomy is a stressful situation for the surgeon, who must seek explanations for said complication. The incidence of post-facectomy diplopia has increased,and an explanation for this fact is the existence of previous undetected pathology, which could have been increased or decompensated by surgery ${ }^{(5)}$. The patient in the present case report denied previous diplopia.Her past medical history showed hyperthyroidism treated with radioactive iodine and which currently was under control with the use of Puran-T4 (due to 
secondary hypothyroidism). Restriction of the extraocular muscles produce incomitant heterotropias with limitation of ductions, and may be caused by dysthyroid orbitopathy, trauma, orbital tumors, etc. ${ }^{(2)}$. The passive forced duction discarded any muscle restriction, although the magnetic resonance suggested thickening of the muscles. The patient had a concomitant strabismus, normal thyroid tests (despite dysthyroid orbitopathy in euthyroid), with no other ocular and orbital signs to diagnose dysthyroid orbitopathy.Myasthenia Gravis is unlikely in the presence of concomitant deviation, with no duction limitation, absence of ptosis,variations over the day, or systemic symptoms such as muscular weakness. ${ }^{(2)}$

Another hypothesis is decompensation of a vertical heterophoria.These cases start up intermittently, developing slowly, which did not happen to this patient. ${ }^{(2)}$

The most probable cause for the patient's diplopia is myotoxicity to the anesthetic used.Gómez-Arnau et al. found an incidence of $0.25 \%$ persistent vertical diplopia after facectomy when the blockade was performed by anesthesiologists.Stratifying such an effect according to the type of blockade, they found an incidence of $0.39 \%$ to retrobulbar blockade, $1 \%$ peribulbar and no case of diplopia after topical or general anesthesia. ${ }^{(6)}$ The use of hyaluronidase reduces the risk of diplopia, since it promotes a better penetration of the injected substances in the tissue planes and better motor blockade and akinesia. ${ }^{(1)}$

Several mechanisms may be involved in diplopia after the anesthetic blockade to perform facectomy.There may be direct injury to the muscle (especially the lower right)by the needle, hemorrhage involving the extrinsic muscles, or myotoxic effect of anesthetics ${ }^{(6)}$. Said complication is usually detected during the postoperative period by the surgeon. A large amount of anesthetic injected into the muscle or perimuscular space can cause increased tissue pressure, secondary vascular impairment, muscle contractures and fibrosis. ${ }^{(6)}$

The patient had a right hipertropia in primary position, with worsening in depression and limitation of elevation, without restriction.Generally, the lesions of the extrinsic muscles are more common on the left side due to greater technical difficulty for right-handed anesthesiologists to perform blockade of this eye.In this case, in contrast, the injury happened in the right eye. ${ }^{(1)}$
As the strabismus presented by the patient was slight in angle and responsive to prisms, the possibility of surgery wasdiscarded.

It was not possible to determinethe precise etiology for diplopia of the patient.However, the authors consider that postoperative diplopia was related to anesthetic damage to the muscles or myotoxicity of drugs used in the anesthetic blockade.The case illustrates how to investigate a case of postfacectomy diplopia complicated by the association to thyroid disease. The authors emphasize the importance of discarding the compromised ocular muscles resulting from severe orbitopathy in such cases before considering the treatment of strabismus and diplopia.

\section{REFERENCES}

1. Strouthidis NG, Sobha S, Lanigan LP, Hammond CJ. Vertical diplopia following peribulbar anesthesia: the role of hyaluronidase. J Pediatr Ophthalmol Strabismus.2004;41(1):25-30.

2. Foroozan R, Arnold AC. Diplopia after cataract surgery. Surv Ophthalmol. 2005;50(1):81-4.

3. Kim JH, Hwang JM. Imaging of the superior rectus in superior rectus overaction after retrobulbar anesthesia. Ophthalmology. 2006;113(9):1681-4.

4. Koide R, Honda M, Kora Y, Ozawa T. Diplopia after cataract surgery. J CataractRefract Surg. 2000;26(8):1198-204.

5. Yangüela J, Gómez-Arnau JI, Martín-Rodrigo JC, Andueza A, Gili P, Paredes B,et al.Diplopia after cataract surgery:comparative results after topical or regional injection anesthesia.Ophthalmology. 2004;111(4):686-92.

6. Gómez-Arnau JI, Yangüela J, González A, Andrés Y, García del Valle S, Gili P,et al. Anaesthesia-related diplopia after cataractsurgery. Br J Anaesth. 2003;90(2):189-93.

\section{Corresponding author:}

Daniel Amorim Leite

Rua Demerval Lobão 1245 Bairro de Fátima - CEP 64048-100 Teresina, PI, Brasil.

E-mail: oftalmodaniel@gmail.com 